RESEARCH ARTICLE

\title{
Soil application of rice husk as a natural silicon source to enhance some chemical defense responses against foliar fungal pathogens and growth performance of Bitter Gourd
} (Momordica charantia L.)

\author{
R. M. R. N. K. Ratnayake', M. Y. U. Ganehenege ${ }^{2}$, H. M. Ariyarathne ${ }^{3}$ and W. A. M. Daundasekera ${ }^{4, *}$ \\ ${ }^{1}$ Postgraduate Institute of Science, University of Peradeniya, Peradeniya, Sri Lanka \\ ${ }^{2}$ Department of Chemistry, Faculty of Science, University of Peradeniya, Peradeniya, Sri Lanka \\ ${ }^{3}$ Horticultural Crop Research and Development Institute, Gannoruwa, Sri Lanka \\ ${ }^{4}$ Department of Botany, Faculty of Science, University of Peradeniya, Peradeniya, Sri Lanka
}

Received:28/09/2017; Accepted:02/02/2018

\begin{abstract}
Rice husk is a natural Silicon ( $\mathrm{Si}$ ) source. This study evaluated the effect of rice husk in two different forms; ground rice husk (GRH) and rice husk ash (RHA) on downy mildew in bitter gourd (Momordica charantia L.) leaves caused by Pseudoperonospora sp. Rice husk was added to the growing medium to achieve the final concentration of $200 \mathrm{mg} \mathrm{Si} / \mathrm{kg}$ soil. Si accumulation in leaves, disease severity, plant growth parameters, cuticle-epidermal layer thickness, chlorophyll content, total phenolic content, peroxidase (POD) and polyphenol oxidase (PPO) activity of leaves were measured. Husk treatment lowered the downy mildew severity significantly $(p<0.05)$ in leaves although the difference between the effects of two husk forms was insignificant. Numbers of leaves, flowers and fruits in husk-treated plants were significantly higher $(\mathrm{p}<0.05)$ than those in control plants. Cuticle-epidermal layer thickness in GRH, RHA-treated and control plants were $16.8 \pm 1.21,18.2 \pm 0.98$ and $13.2 \pm 1.27 \mu \mathrm{m}$ respectively. Total phenol content, POD, PPO activity and chlorophyll content in rice husk-treated plants were significantly $(p<0.05)$ higher than that of control plants. The enhanced disease resistance in rice husk-treated plants appears to be positively associated with the higher accumulation of silicon and Si-enhanced phenolic content and increased activity of PPO and POD enzymes in leaves.
\end{abstract}

Keywords: Bitter gourd, silicon, rice husk, foliar diseases.

\section{INTRODUCTION}

Rice husk $(\mathrm{RH})$ is the sheath which forms the cover of rice grains during their growth. It is one of the most widely available agricultural by-products in rice producing countries throughout the world, which accounts for $20 \%$ of the annual world rice production (Battegazzore et al., 2014). Currently, rice husk is used for different purposes; as a fuel, as material for animal husbandry, as biofertilizer, as a raw material for construction industry etc. However, it is still an under-utilized product of rice milling and thus often burned in open air or dumped on wasteland. Rice husk ash (RHA) is produced during the combustion of rice husk. When burning temperature is not uniform, it may yield different types of RHA; black, gray or white. In fully burnt $\mathrm{RH}$, silica $\left(\mathrm{SiO}_{2}\right)$ is the main component which accounts for more than $95 \%$ of total elements present
(Haslinawati, et al., 2009). Numerous reports suggest that black to gray RHA can be effectively used in rice nurseries and in the main rice fields to achieve healthy seedlings and higher yields. According to Ishibashi (1956) carbonized $\mathrm{RH}$ is a good source of Silicon (Si) while unprocessed $\mathrm{RH}$ is not. Moreover, amendment of soil with ground RH was found to enhance the yield of cowpea (Aliyu et al., 2011) whereas composted RH was also useful in improving growth and some biochemical parameters including chlorophyll content, total carbohydrates and crude protein content in sunflower plant (Badar et al., 2014). As reported by Jayawardane et al. (2014), leachates from RH (which was produced by soaking $\mathrm{RH}$ in water) was effective in enhancing growth, yield and resistance against anthracnose disease in capsicum.

Though Si not considered as an essential element for plant growth, many beneficial effects of Si have been especially documented in 'Si-accumulator' plants like wheat, barley and rice (Ma et al., 2001). These include alleviation of abiotic stresses and suppression of diseases in several plant species. The Si-mediated resistance to pathogen infection has mostly been related to activation of (i) physical defense mechanisms such as formation of papillae and cuticle-Si double layer; (ii) activation of chemical defense such as defense-related enzymes and production of antimicrobial substances; and (iii) molecular mechanisms including transcryptomic and proteomic regulation in plants (Wang et al., 2017). Potassium silicate $\left(\mathrm{K}_{2} \mathrm{SiO}_{3}\right)$, a highly soluble form of $\mathrm{Si}$, has been widely studied for its beneficial effects in controlling diseases in many crops.

We previously reported that the root application of soluble $\mathrm{Si}$ (in the form of $\mathrm{K}_{2} \mathrm{SiO}_{3}$ ) reduces the severity of major foliar fungal diseases in bitter gourd (Momordica charantia L.) including powdery mildew caused by Erysiphe $s p$. and downy mildew caused by Pseudoperonospora sp. (Ratnayake et al., 2014, 2015, 2016a and 2016b). The reduction of disease severity could partly be attributed to Si-enhanced chemical defense responses including elevated activity of enzymes; peroxidase, polyphenol oxidase and pathogenesis-related proteins; chitinase and $\beta$-1, 3-glucanase in leaf tissues (Ratnayake et al., 2016c). In this context, the aims of the current work were to ascertain 
the effectiveness of soil amendment with rice husk as a natural Si source in controlling foliar fungal diseases, and the effects on some growth and yield parameters of bitter gourd plant.

\section{MATERIALS AND METHODS}

\section{Plant material and growth media}

Momordica charantia L. cultivar 'Matale green' plants were grown on plastic pots containing sand: top soil: compost at $2: 1: 1$ ratio as the growth medium. The concentration of available $\mathrm{Si}$ in this medium was $2.9 \mathrm{mg} / \mathrm{L}$, as assayed by colorimetry (Snyder, 2001) after extraction with $\mathrm{Na}_{2} \mathrm{CO}_{3} /$ $\mathrm{NH}_{4} \mathrm{NO}_{3}$ (Buck et al., 2010). The pots were arranged in a plant house at the Department of Botany, University of Peradeniya, Sri Lanka $\left(7.0-9.0^{\circ} \mathrm{N} ; 81-82^{\circ} \mathrm{E}\right)$ with $1.5 \mathrm{~m}$ $\mathrm{x} 1.5 \mathrm{~m}$ plant spacing. Rice husk was used in two different forms viz. ground rice husk (GRH), which was obtained by grinding the rice husk on laboratory scale grinder and rice husk ash (RHA), which was obtained by burning in a Muffle furnace at $500^{\circ} \mathrm{C}$ for 5 hours. The plant available Si in each form of husk was quantified before adding to the growth media. The husk was added to the growth media to achieve a final concentration of $200 \mathrm{ppm} \mathrm{Si} / \mathrm{kg}$ (plant available $\mathrm{Si}$ ). This $200 \mathrm{ppm} \mathrm{Si} / \mathrm{kg}$ soil has been identified previously by us as the best Si concentration to be used on bitter gourd to control foliar fungal diseases (Ratnayake et al., 2016a). Amendment of growth media with RH was started at the four leaf stage of plantlets and continued up to 28 days at seven- day intervals. Plants grown on media without rice husk served as controls. Each treatment consisted of 20 replicate plants and the experiment was repeated twice.

\section{Plant-available Si content in rice husk}

Soluble Si contents in GRH and RHA were measured by colorimetric analysis (Snyder, 2001) after extraction using the method of Nonaka and Takahashi (1988). Ten grams $(10 \mathrm{~g})$ of each sample was mixed in $60 \mathrm{ml}$ of water and shaken for 1 hour, then kept undisturbed for one week at 40 ${ }^{\circ} \mathrm{C}$ before determination of soluble Si content.

\section{Total Si levels in leaves along plant growth}

A time course analysis of the total soluble Si levels in leaves from different treatments was done starting at 35 days after the first dose of husk application and continued up to 77 days at seven-day intervals (Rice husk was applied up to 28 days, and $\mathrm{Si}$ analysis was started at 35 days. Our observations revealed that initial fruit set occurs at 70-77 days after the first Si treatment. Therefore data were taken up to 77 days).

Extraction and analysis of Si were as described by us recently (Ratnayake et al., 2016a). Five leaves, between $15^{\text {th }}-60^{\text {th }}$ nodes from each plant, were oven dried at 70 ${ }^{\circ} \mathrm{C}$ for three days and the $\mathrm{Si}$ contents of the powdered and autoclave-digested samples were determined by colorimetric analysis (Snyder, 2001).

\section{Plant growth}

Number of leaves, flowers, and fruits per plant were counted at seven days interval starting from 35 days after the first husk application.

\section{Disease severity in leaves}

Severity of downy mildew disease (the most common disease during the period of investigation) in leaves was rated separately through external observations on weekly basis using a self-prepared scale $(0=$ no disease, $1=1$ to $20 \%, 2=21$ to $40 \%, 3=41$ to $60 \%, 4=61$ to $80 \%$, and 5 $=81$ to $100 \%$ of upper leaf surface covered with disease) (Ratnayake et al., 2016b). As all the treated and control plants were arranged randomly in the field and fertilization, watering and other field practices were applied similarly to each pot, it was assumed that all the plants got identical level of inoculums.

\section{Structural changes in leaves}

Transverse sections (TS) of leaves obtained from the plants with different treatments were observed under light microscope and cuticle-epidermal layer thickness was measured. Prior to the appearance of disease, 42 days after the first dose of husk application, 5 leaves between $5^{\text {th }}-10^{\text {th }}$ node of each plant were tagged, and randomly selected 10 leaves from the tagged leaves were removed per treatment for anatomical study.

\section{Total phenolic content, peroxidase (POD) and polyphenol oxidase (PPO) activity of leaves}

\section{Preparation of leaf samples}

Thirty five days after the first husk application, three to four leaves between $10^{\text {th }}-15^{\text {th }}$ node of the plant were selected and their fresh weights were noted before extraction for enzyme analysis.

\section{Total phenolic content of leaves}

Leaf samples were extracted for phenolic compounds with $80 \%$ (v/v) methanol (Torti et al., 1995) and the total phenolic content was determined using Folin-Ciocalteu assay using gallic acid as the phenolic standard (Singleton et al., 1999). Absorbance was measured on a Spectrophotometer (Thermo Spectronic) at $760 \mathrm{~nm}$ against methanol blank. Total phenolic content was expressed in $\mathrm{mg}$ of gallic acid equivalents (GAE) /100 g (dry weight) of leaf.

\section{Peroxidase (POD) assay}

The POD activity of the leaf extract was determined as described recently for bitter gourd (Ratnayke et al., 2016c) by measuring the appearance of pink/brown colour resulting from guaiacol oxidation in the presence of hydrogen peroxide (Dann and Deverall, 2000). Appropriately diluted plant extract $(50$ or $100 \mu \mathrm{L})$ was added to the reaction mixture and the absorbance was measured on a Spectrophotometer at $470 \mathrm{~nm}$ every $10 \mathrm{~s}$ for $60 \mathrm{~s}$. The activity of POD was detected as change in absorbance at $470 \mathrm{~nm}$ and expressed in min $^{-1} \mathrm{mg}_{\text {protein }}{ }^{-1}$. 


\section{Polyphenol oxidase (PPO) assay}

Method used to extract PPO was based on our previous experiments (Ratnayake et al., 2016c). This method involved spectrophotometric measurement of the change in intensity of a dark coloured polymeric compound resulted from oxidation of catechol of the reaction mixture upon adding leaf extracts. The enzyme activity in the plant extract was expressed in $\min ^{-1} \mathrm{mg}$ protein ${ }^{-1}$ upon calculating the change in absorbance at $400 \mathrm{~nm}$ (Cheriff et al., 1994).

\section{Chlorophyll content of leaves}

Two leaves excised at $10^{\text {th }}-12^{\text {th }}$ nodes of the vine per replicate plant at 35 days after first husk application were used. Prior to extraction, leaf samples were cleaned with deionized water to remove any surface contamination. Five grams ( $5 \mathrm{~g}$ ) of fresh leaf tissue was extracted with $80 \%$ acetone, filtered and the absorbance was measured at $643 \mathrm{~nm}$ and $660 \mathrm{~nm}$ on a Spectrophotometer. Chlorophyll content was calculated according to the method of AOAC (2000).

\section{Data analysis}

Data were analyzed using ANOVA using SAS statistical software for windows version 9.0. Differences between treatment means were obtained by DMRT at $\mathrm{p}<0.05$.

\section{RESULTS AND DISCUSSION}

\section{Plant-available Si content in rice husk}

As measured by spectrophotometry, plant-available (soluble) Si content in RHA $(56.1 \pm 2.1 \%)$ was significantly greater $(p<0.05)$ than that in GRH $(18.2 \pm 2.4 \%)$. Thus the amount of RHA needed to achieve $200 \mathrm{ppm}(0.36 \mathrm{~g} /$ $\mathrm{kg}$ soil) was lesser than that of GRH (1.1 $/ \mathrm{kg}$ soil). High processing temperatures regularly release $\mathrm{Si}$ from tightly bound state and as a result, solubility increases (Gascho, 2001). This may be due to the increased level of soluble
$\mathrm{Si}$ in RHA. Beneficial effects of carbonized rice husk (CRH; partially burnt $\mathrm{RH}$ ) on plant growth had also been reported (Haefele et al., 2011). However, our preliminary investigations revealed that the presence of carbonized rice husk (partially burnt) in growth media ( $1 \mathrm{~g} / \mathrm{kg}$ soil) hinder the growth of bitter gourd plants (data not shown). It may have resulted from the changes resulted by burned husk on $\mathrm{pH}$ and especially due to increased $\mathrm{C} / \mathrm{N}$ ratio in soil. The property/form of rice husk added to soil appears to determine the overall performance of plant through their effects on soil hydro-physical properties. The changes in soil in turn neutralize the soil acidity and increase nutrient availability to plants (Sandrini, 2010). The magnitude of these effects depends on the characteristics of rice husk.

\section{Si accumulation in leaves along plant growth}

All rice husk treated plants exhibited significantly higher $(p<0.05)$ Si levels in leaves compared to those from nontreated plants. Both GRH and RHA were equally effective in elevating the total $\mathrm{Si}$ contents of leaves. A gradual increase in total $\mathrm{Si}$ content up to 42 days was observed in husk-treated plants. About 70-77 days after first husk application, $\mathrm{Si}$ contents in leaves dropped to the levels similar to those in non-treated controls (Figure 1).

\section{Disease severity in leaves}

Downy mildew, most common disease during the study period was identified by its typical symptoms (Kuepper, 2003). The causative fungus was identified as a Pseudoperonospora sp. based on fungal morphological characteristics including lemon shaped conidia borne at the branched pointed tips of sporangiophores (Palti, 1975). Symptoms started to appear first in control plants by 35 days after seedling emergence whereas disease appearance was delayed by 9 days in rice husk-treated plants (Figure 2 ). It was interesting to note that, disease severity of rice husk treated plants was significantly lower $(\mathrm{P}<0.05)$ than that of control plants during the entire period of experiment

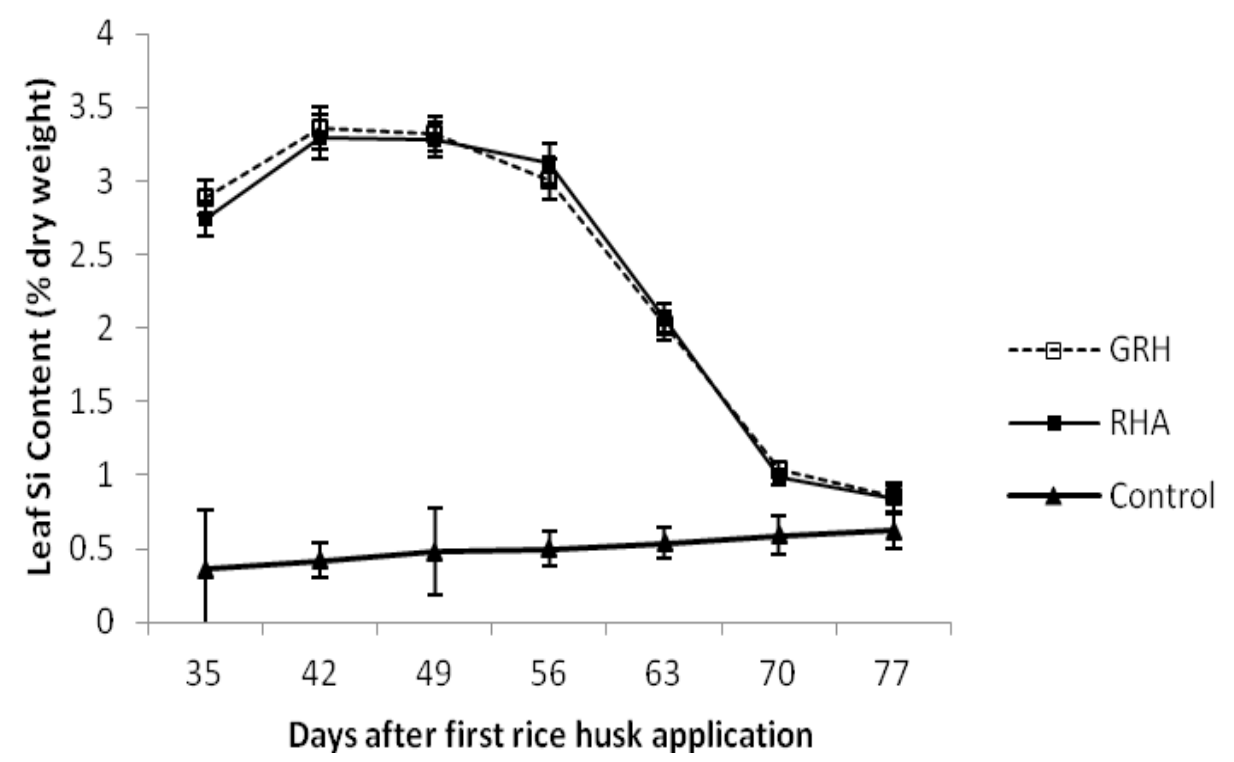

Figure 1: Changes in Si accumulation in bitter gourd leaves over time. (Husk application was started at 4 leaf stage and continued up to 28 days at seven-day intervals). (GRH = ground rice husk; $\mathrm{RHA}=$ rice husk ash). 


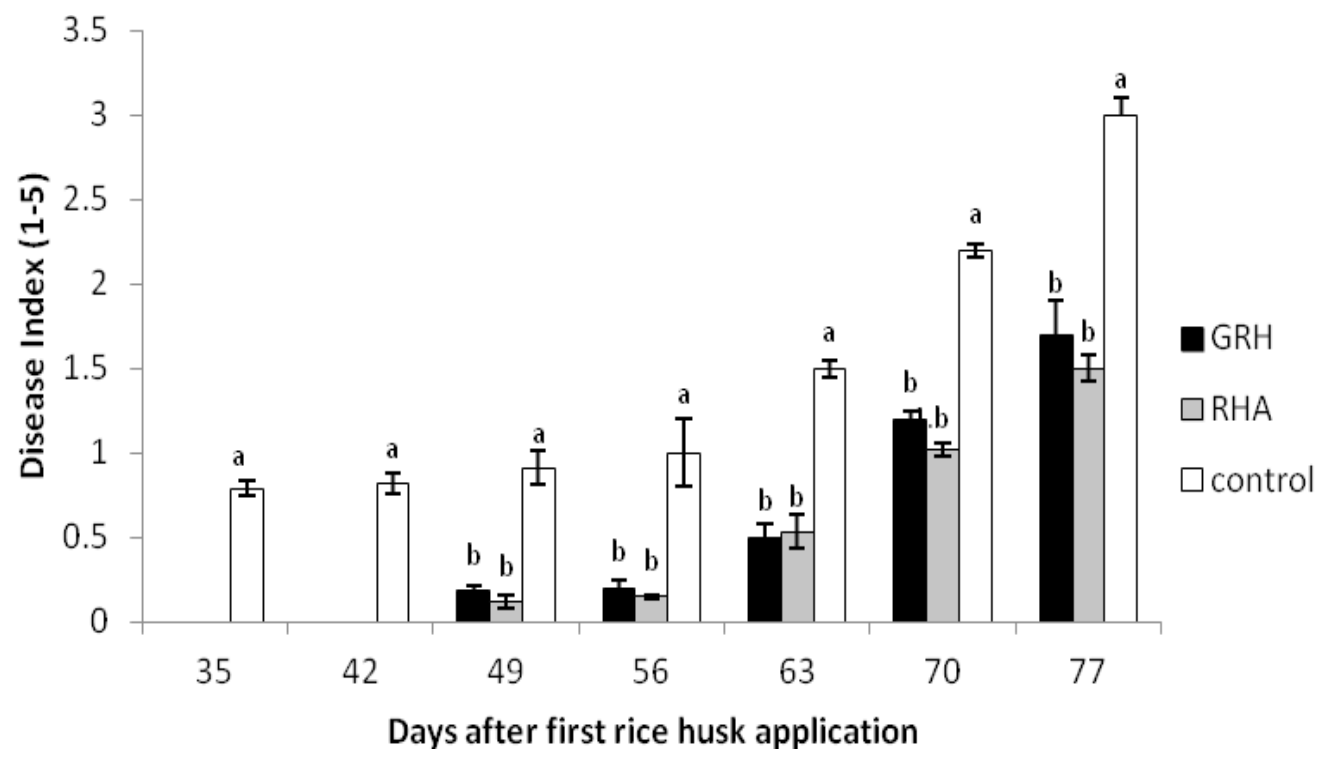

Figure 2: Variation of the disease severity on bitter gourd leaves due to the different silicon concentrations. Different letters above bars under each day indicates significant difference at $\mathrm{P}<0.05$. (GRH $=$ Ground rice husk; RHA $=$ Rice husk ash $)$. Disease index $0=$ No disease, $5=81-100 \%$ of upper leaf surface covered with the disease).

Table 1: Variation in leaf, flower and fruit number per bitter gourd plant with different rice husk treatments.

\begin{tabular}{llll}
\hline Treatment & Leaves & Flowers & Fruits \\
\hline GRH & $83.2^{\mathrm{a}}$ & $6.86^{\mathrm{b}}$ & $3.68^{\mathrm{a}}$ \\
RHA & $82.4^{\mathrm{a}}$ & $7.18^{\mathrm{a}}$ & $3.74^{\mathrm{a}}$ \\
Control & $78.4^{\mathrm{b}}$ & $5.95^{\mathrm{c}}$ & $3.12^{\mathrm{b}}$ \\
\hline
\end{tabular}

Observations made at 70 days after first husk application $(\mathrm{GRH}=$ ground rice husk; RHA = rice husk ash). Mean values followed by different letters under each column are significantly different at $\mathrm{P}<0.05$.

and both GRH and RHA were equally effective in reducing the disease severity. A clear reduction in downy mildew severity and levels of leaf accumulated $\mathrm{Si}$ was reported recently for bitter gourd plants grown in potassium silicateamended media (Ratnayake et al., 2016b). The reduction of disease severity and levels of foliar accumulated $\mathrm{Si}$ in plants grown on rice husk-amended media were comparable with those grown in potassium silicate- amended media.

\section{Plant growth and chlorophyll content of leaves}

A significantly higher $(\mathrm{P}<0.05)$ numbers of leaves, flowers and fruits per plant were observed in husk-treated plants (irrespective of the form of husk used) compared to control plants (Table 1). Total chlorophyll contents in husk-treated plants were also significantly higher $(\mathrm{P}<0.05)$ than that of control plants (Table 2). Improved growth characteristics in plants grown in husk-amended media also could be attributed to increased availability of soluble $\mathrm{Si}$ to plants. This observation agrees with the findings that root application of potassium silicate improves growth and yield parameters of bitter gourd plant (Ratnayake et al., 2016c). A positive correlation between soluble Si application and enhanced productivity has been reported for many crops such as barley, corn, chili, cucumber, tomato, sugarcane and wheat (Meena et al., 2014; Jayawardana et al., 2016). Elevated chlorophyll levels may have partly contributed to the increased yield of bitter gourd plants. Si applications have reported to enhance photosynthetic efficiency by enhancing tiller and leaf formation in several crops (Meena et al., 2014). Moreover, Si-induced strengthening of the leaf prevents leaf drooping thus contributing to enhanced light capturing capacity during photosynthesis (Donega et al., 2009). Zhu et al. (2004) observed that Si - induced increase in total chlorophyll content in leaves can also be related to the extent of thylakoid stacking.

An increased uptake of $\mathrm{N}$ levels was observed in bitter gourd plants grown in husk-amended media (Ratnayake et al., 2017). Si has the ability to increase the levels of some nutrients such as $\mathrm{N}$ and $\mathrm{P}$ thus resulting boosted yields of many cereal crops including rice (Singh et al., 2006). However, a reduction in $\mathrm{N}$ uptake has also been reported for certain crops with Si application (Horiguchi, 1988).

\section{Structural changes in leaves}

The thickness of the cuticle - epidermal layer in transverse sections of leaves in rice husk-treated plants was significantly higher $(\mathrm{P}<0.05)$ than that of the control plants. The highest thickness was observed in RHA-treated plants $(18.2 \pm 0.98 \mu \mathrm{m})$ compared to that in GRH-treated plants $(16.8 \pm 1.21 \mu \mathrm{m})$ and non-treated plants $(13.2 \pm 1.27 \mu \mathrm{m})$. The increased cuticle-epidermal layer thickness of bitter 
Table 2: Effect of ground rice husk (GRH) and Rice husk ash (RHA) on chlorophyll contents in bitter gourd leaves.

\begin{tabular}{lccc}
\hline Type of Chlorophyll $(\mathbf{m g} / \mathbf{L})^{*}$ & RHA & GRH & Control \\
\hline Chlorophyll a & $14.47 \pm 0.28^{\mathrm{a}}$ & $14.53 \pm 0.94^{\mathrm{a}}$ & $9.12 \pm 0.76^{\mathrm{b}}$ \\
Chlorophyll b & $8.61 \pm 1.34^{\mathrm{a}}$ & $8.64 \pm 0.98^{\mathrm{a}}$ & $5.98 \pm 1.32^{\mathrm{a}}$ \\
Total Chlorophyll & $22.94 \pm 1.64^{\mathrm{a}}$ & $22.87 \pm 1.98^{\mathrm{a}}$ & $15.94 \pm 2.31^{\mathrm{b}}$ \\
\hline
\end{tabular}

*Data represent the analysis of leaf tissues on $70^{\text {th }}$ day after first husk application. Mean values followed by different letters under each row are significantly different at $\mathrm{P}<0.05$. RHA $=$ rice husk ash $\mathrm{GRH}=$ ground raw rice husk.

Table 3: Effect of rice husk ash (RHA) and ground raw rice husk (GRH) on total phenol content, activities of peroxidase and polyphenol oxidase enzymes in bitter gourd leaves.

\begin{tabular}{|c|c|c|c|}
\hline Parameter & GRH & RHA & Control \\
\hline Total Phenol (mg GAE/100 g leaf dw) & $150.32^{\mathrm{b}}$ & $153.20^{\mathrm{a}}$ & $135.51^{\mathrm{c}}$ \\
\hline POD activity ( $\Delta$ absorbance at $400 \mathrm{~nm}$ min $-1 \mathrm{mg}$ protein $\left.{ }^{-1}\right)$ & $2.060^{\mathrm{b}}$ & $2.340^{\mathrm{a}}$ & $1.840^{\mathrm{c}}$ \\
\hline PPO activity ( $\Delta$ absorbance at $\left.400 \mathrm{~nm} \min ^{-1} \mathrm{mg}_{\text {protein }}{ }^{-1}\right)$ & $0.029^{\mathrm{a}}$ & $0.031^{\mathrm{a}}$ & $0.022^{\mathrm{b}}$ \\
\hline
\end{tabular}

gourd plants raised on husk-amended media may have contributed partly to their enhanced resistance to fungal disease. Si in the solution of growth medium is absorbed in to the plant in the form of monosilicic acid $\left(\mathrm{H}_{4} \mathrm{SiO}_{4}\right)$ and is transported from root to shoot through the water current in the xylem (Ma et al., 2003). Once transported to the leaves through transpiration stream, monosilicic acid can get concentrated beneath the cuticle in the leaf epidermal cells thus forming double-cuticular layer. Further increase of soluble Si levels in leaves may lead monosilicic acid to polymerize into amorphous $\mathrm{SiO}_{2}$ (Yoshida, 1975). Si deposited on the epidermis provides an additional barrier to pathogen invasion thereby making the plants more resistant to diseases (Heine et al., 2007).

\section{Total phenolic content of leaves}

Total phenol contents, PPO and POD enzyme activities in leaves from rice husk- treated plants were significantly higher than those of control plants. RHA was more effective than GRH in elevating the total phenol content and POD activity (Table 3). The progress of infection leads to a range of defense responses in the host. Various antimicrobial compounds in plants such as phenols are involved in early defense responses (Osbourn, 1996). Peroxidases and other phenol oxidizing enzymes convert phenolics to more toxic forms that are inhibitory to the pathogenic growth (Kuvalekar et al., 2011). Thus, POD and PPO play an important role in plant stress caused by different stimuli including fungal pathogens, wounding or abiotic stress. Increased epidermal-cuticle layer thickness observed in this study may partly be related to the increased level of POD activity that has a specific role in lignification and strengthening the plant cell wall that is highly resistant to biodegradation (Schoemaker and Piontek 1996; Lee et al., 2007; Jaiti et al., 2009). Further, PPO contributes to lignification (Ralph et al., 2008) and together with POD it consumes oxygen and produces quinones, which may be toxic to pathogens. Therefore, decrease in disease progress in rice husk treated plants suggests the relationship with phenols and tested enzymes in the study. On the other hand, impregnation of epidermal cell walls with silica in rise huskamended plants may also have made the initial penetration difficult for the downy mildew pathogen (Heath and Stumf, 1986). Furthermore, silica treatment provides resistance to mildew fungi through papillae formation and deposition of callose in the epidermal cell walls (Bélanger et al., 2003). Defense against direct-penetrating fungi including biotrophs causing rust and mildews is more successful when they fail to penetrate the epidermal cell wall, the first line of defense in the host plant (Heath, 2002).

When comparing with our previous observations with potassium silicate effects on bitter gourd (Ratnayake et al., 2016c), it was clear that foliar disease severity gradually decreased after the husk application was stopped. Once $\mathrm{Si}$ is deposited in a plant tissue in the polymerized form it is not remobilized within the plant (Raven, 1983). Presence of soluble $\mathrm{Si}$ in plant tissues is necessary to maintain the disease resistance against pathogens. Therefore, depletion of soluble Si from growth media may lead to gradual loss of plant resistance to pathogens. In addition to the resistance mechanisms described above, Si-induced fungitoxic activity also may play a role in disease resistance as observed previously with bitter gourd grown on potassium silicateamended media (Ratnayake et al., 2016c). A positive relationship between $\mathrm{Si}$-induced fungitoxic compounds and resistance against fungal diseases has been reported for many other horticultural crops (Van Bockhaven et al., 2013).

When considering the interaction between the biotrophic pathogen and a host plant, haustoria play a vital role as highly specialized structures through which nutrients are uptaken from the host cells. The pathogen haustorium does not have a direct contact with the host cytoplasm and the nutrient uptake takes place via an 'extracellular matrix' 
which encircles the haustorium. This matrix also acts as a buffer protecting the pathogen from toxins and enzymatic hydrolysis in the course of plant defense responses (Voegele and Mendgen, 2003). Therefore, further investigation is necessary for revealing the mechanism/s underlying the effects of Si-enhanced fungitoxic compounds on downy mildew pathogen on bitter gourd.

\section{CONCLUSION}

Rice husk in raw or ash form improves growth and yield characters and enhances resistance to foliar fungal pathogens in bitter gourd. The enhanced disease resistance in rice husk-treated plants appears to be positively associated with the higher accumulation of silicon and Siinduced phenolic content and increased activity of PPO and POD enzymes in leaves. Rice husk ash (RHA) can be recommended as more effective and easy-to-use form of husk than ground raw husk (GRH) that can be incorporated into potting mixtures and agricultural fields. Rice husk can be suggested as an eco-friendly low cost alternative to fungicides with several added beneficial effects that can be used in bitter gourd cultivation.

\section{ACKNOWLEDGEMENT}

Financial assistance by the National Research Council of Sri Lanka under the Grant Number NRC 11/118 is highly appreciated.

\section{REFERENCES}

Aliyu, T.H., Balogun, O.S. and Alade, O.O. (2011). Assessment of the effect of rate and time of application of rice-husk powder as an organic amendment on cowpea (Vigna unguiculata L.,walp) inoculated with cowpea mottle virus. Agriculture and Biology Journal of North America 2(1): 74-79.

AOAC (2000). Official Method of Analysis of AOAC International (Vol. II). Suite 500 481, North Frederick Avenue, Gaithersburg, Maryland 20877-2417. USA.

Badar, R. and Qureshi, S.A. (2014). Composted rice husk improves the growth and biochemical parameters of sunflower plant. Journal of Botany, Article ID 427648: 6 pages.

Battigazzore, D., Bochini, S., Alongi, J. and Frache, A. (2014). Rice husk as biosource of silica: preparation and characterization of PLA-silica bio composites. RSC Advances 4: 5470-5471

Bélanger, R.R., Benhamou, N. and Menzies, J.G. (2003). Cytological evidence of an active role of silicon in wheat resistance to powdery mildew (Blumeria graminis f. sp. tritici). Phytopathology 93: 402-412.

Buck, G.B., Korndorfer, G.H. and Datnoff, L. E. (2010). Extractors for estimating plant available silicon from potential silicon fertilizer sources, Journal of Plant Nutrition 34(2): 272-282.

Cherif, M., Asselin, A. and Belanger, R.R. (1994). Defense response induced by soluble silicon in cucumber roots infected by Pythium sp. Phytopathology 84(3): 236242 .
Dann, E.K and Deverall, B.J. (2000). Activation of systemic diseases resistance in pea by an avirulent bacterium or benzothiadiazole, but not by a fungal leaf spot pathogen. Plant Pathology 49: 324-332.

Donega M.A. (2009). Ratio K:Ca and application of silicon in the nutrient solution for the hydroponic cultivation of coriander. (MSc. Dissertation) Piracicaba High School of the Agriculture, Luiz de Queiroz, 1-62.

Gascho, G.J. (2001). Silicon deposition in higher plants. In: L.E. Datnoff, G.H. Snyder and G.H. Korndorfer (Eds.), Silicon in Agriculture, Elsevier Science B.V. Amsterdam, The Netherlands. 197-207.

Haefele, S.M., Konboon, Y., Wongboon, W., Amarante, S., Maarifat, A.A., Pfeiffer, E. M. and Knoblauch, C. (2011). Effects and fate of biochar from rice residues in rice-based systems. Field Crops Research 121(3): 430440.

Haslinawati, M.M., Matori, K.A., Wahab, Z.A., Sidek, H.A.A., and Zainal, A.T. (2009). Effect of temperature on ceramic from rice husk ash. International Journal of Basic \& Applied Sciences, 9(9): 22-25.

Heath, M.C. (2002). Cellular interactions between biotrophic fungal pathogens and host or nonhost plants. Canadian Journal of Plant Pathology 24: 259-264.

Heath , M.C. and Stumpf, M.A. (1986). Ultrastuctural observations of penetration sites of the cowpea rust fungus in untreated and silicon-depleted French bean cells. Physiological and Molecular Plant Pathology 29: 27-39.

Heine, G., Tikum, G. and Horsi, W.J. (2007). The effect of silicon on the infection by and spread of Pythium aphanidermatum in single roots of tomato and bitter gourd. Journal of Experimental Botany 58(3): 569-577.

Horiguchi, T. (1988). Effect of silicon on alleviation of Mn toxicity of rice plants. Soil Science and Plant Nutrition 34: 65-73.

Ishibashi, H. (1956). Effect of silica contained in carbonized husk on the growth of rice seedlings. Bulletin of the Faculty of Agriculture. Yamagushi University 7: 333340.

Jaiti, F., Verdeil, J.L., El hadrami, I. (2009). Effect of jasmonic acid on the induction of polyphenoloxidase and peroxidase activities in relation to date palm resistance against Fusarium oxysporum f. sp. albedinis. Physiological and Molecular Plant Pathology 24: 84-90.

Jayawardana, R.K., Weerahewa, D., Saparamadu, J. (2016). The effect of rice hull as a silicon source on anthracnose disease resistance and some growth and fruit parameters of capsicum grown in simplified hydroponics. International Journal of Recycling Organic Waste in Agriculture 5(1):9-15

Jayawardana, H.A.R.K., Weerahewa, H.L.D. and Saparamadu, M.D.J.S. (2014). Silicon supplimentation by rice hull leachate on the growth, yield, fruit parameters and anthracnose disease resistance of capsicum 'MuriaF1'. International Journal of Multidisciplinary Studies 1(1): 33-39.

Kuepper, G. (2003). Downy Mildew Control in Cucurbits. ATTRA, US Department of Agriculture. http://www. attra.ncat.org/attra-pub/PDF/downymil.pdf Accessed 
on 20.09.2017

Kuvalekar, A., Redkar, A., Gandhe, K. and Harsulkar, A. (2011). Peroxidase and polyphenol oxidase activities in compatible host-pathogen interaction in Jasminum officinale and Uromyces hobsoni: Insights into susceptibility of host. New Zealand Journal of Botany 49(3): 351-359.

Lee, B.R., Kim, K.Y., Jung, W.J., Avice, J.C., Ourry, A. and Kim, T.H. (2007). Peroxidases and lignification in relation to the intensity of water-deficit stress in white clover (Trifolium repens L.). Journal of Experimental Botany 58: 1271-1279.

Ma, J.F., Higashitani, A., Sato, K., Tateda, K. (2003). Genotypic variation in Si content of barley grain. Plant Soil 249: 383-387.

Ma, J.F., Miyake, Y., Takahashi, E. (2001). Silicon as a beneficial element for crop plants. In: L.E. Datnoff, G.H. Snyder and G.H. Korndorfer (Eds.), Silicon in Agriculture, Elsevier Science B.V. Amsterdam, The Netherlands. 17-39

Meena, V.D., Dotania, M.L., Coumar, V., Rajendran, S. Ajay., Kundu, S. and Rao, S. (2014). A case for silicon fertilization to improve crop yields in tropical soils. Proceedings of National Acadamy of Science, India. 84(3): 505-518.

Nonaka, K., Takahashi, K. (1988). A method of measuring available silicates in paddy soils. Japan Agricultural Research Quarterly 22: 91-95.

Osbourn, A.E. (1996). Preformed antimicrobial compounds and plant defense against fungal attack. The Plant Cell 8: $1821-1831$.

Palti, J. (1975). Pseudoperonospora cubensis. IMI Descriptions of Fungi and Bacteria CAB International, UK No. 46, 457p.

Ralph, J., Brunow, G., Harris, P.J., Dixon, R.A., Schatz, P.F., Boerjan, W. (2008). Lignification: are lignins biosynthesized via simple combinatorial chemistry or via proteinaceous control and template replication? Recent Advances in Polyphenol Research 1:36-66.

Ratnayake, R.M.R.N.K., Daundasekera, W.A.M., Ariyarathne, H. M. and Ganehenege, M. Y. U. (2016a). Effect of rice husk as a natural silicon source to control preharvest fungal diseases in bitter gourd leaves. Proceedings of the PGIS Research Congress 2016. Postgraduate Institute of Science, University of Peradeniya, Sri Lanka. p65.

Ratnayake, R.M.R.N.K., Daundasekera, W.A.M., Ariyarathne, H.M. and Ganehenege, M.Y.U. (2016b). Soil application of potassium silicate reduces the intensity of downy mildew in bitter gourd (Momordica charantia L.) leaves. Ceylon Journal of Science 45(1): 23-31.

Ratnayake, R.M.R.N.K., Daundasekera, W.A.M., Ariyarathne, H.M. and Ganehenege, M.Y.U. (2016c). Some biochemical defense responses enhanced by soluble silicon in bitter gourd-powdery mildew pathosystem. Australasian Plant Pathology 45: 425433.

Ratnayake, R.M.R.N.K., Daundasekera, W.A.M., Ariyarathne, H.M. and Ganehenege, M.Y.U.(2015). Effect of silicon application on downy mildew in bitter gourd (Momordica charantia L.) leaves. Proceedings of the Young Scientists Forum Symposium 2014, National Science and Technology Commission, Sri Lanka. Pp163-166.

Ratnayake R.M.R.N.K., Daundasekera, W.A.M., Ariyarathne H.M. and Ganehenege, M.Y.U. (2014). Effect of silicon application on fungal diseases in bitter gourd (Momordica charantia L.) leaves. Proceedings of the PGIS Research Congress 2014. Postgraduate Institute of Science, University of Peradeniya, Sri Lanka. p74.

Raven, J.A. (1983). The transport and function of silicon in plants. Biological Reviews 58( 2): 179-207.

Sandrini, W.C. (2010). Chemical and microbiological soil changes due to the addition of rice husk ash. Pelotas, Federal University of Pelotas. (MSc dissertation). 70p.

Schoemaker, H.E. and Piontek, K. (1996). On the interaction of lignin peroxidase with lignin. Pure and Applied Chemistry 68(11): 2089-2096.

Singh, K., Singh, R., Singh, J.P., Singh, Y., Singh, K.K. (2006). Effect of level and time of silicon application on growth, yield and its uptake by rice (Oryza sativa). Indian Journal of Agricultural Sciences 76(7): 410-413.

Singleton, V.L., Orthofer, R., Lamuela-Raventos, R.M. (1999). Analysis of total phenols and other oxidation substrates and antioxidants by means of Folin-Ciocalteu reagent. Methods of Enzymology 299: 152-178.

Snyder, G.H. (2001). Methods for silicon analysis in plants, soils and fertilizers. Studies in Plant Science 8: 185-196.

Torti, S.D., Dearing, M.D. and Kursar, T.A. (1995). Extraction of phenolic compounds from fresh leaves: A comparison of methods. Journal of Chemical Ecology 21(2), 117-125.

Van Bockhaven J., De Vleesschauwer, D. and Hofte, M. (2013). Towards establishing broad-spectrum disease resistance in plants: silicon leads the way. Journal of Experimental Botany 64(5): 1281-1293.

Voegele, R.T. and Mendgen, K. (2003). Rust haustoria: nutrient uptake and beyond. New Phytologist 159: 93100.

Wang, M., Gao, L., Dong, S., Sun, Y., Shen, Q. and Guo, S. (2017). Role of Silicon on Plant-Pathogen Interactions. Frontiers in Plant Science 8: 701.

Yoshida S (1975). The physiology of silicon in rice. Food Fertilizer Technology. Centre Technical Bulletin. No. 25

Zhu, Z.J., Wei, G.Q., Li, J, Qian, Q.Q. and Yu, J.P. (2004). Silicon alleviates salt stress and increases antioxidant enzymes activity in leaves of salt-stressed cucumber (Cucumis sativus L.). Plant Science 167: 527-533. 